\title{
TOWARDS REVITALIZATION OF INSTRUCTIONAL LEADERSHIP FOR EFFECTIVE IMPLEMENTATION OF UNIVERSAL BASIC EDUCATION IN NIGERIA
}

\author{
BELLO AHMAD BELLO
}

Department of Education, Bayero University Kano, Nigeria.

\begin{abstract}
This paper examined the needs to revitalize instructional leadership of primary and junior secondary schools headteachers in Nigeria, for successful implementation of the Universal Basic Education (UBE) Programme. Instructional leadership, as viewed in the paper, has to do with creating a school culture that makes students' learning a priority and provides the resources necessary to support teachers' efforts to improve students' learning. The need for revitalization of instructional leadership in the Nigerian Basic Education schools emanates from the identified problems of lack of clearly defined general instructional visions in the schools in question, dearth of instructional materials, ineffective instructional supervision by the headteachers, and absence of school-based professional development programmes for teachers. With the introduction of UBE and subsequent curricular review, the paper discovered that there was the need to re-orient teachers towards effective teaching of the newly infused contents of the 9-year basic education curriculum. The paper, based on the identified needs for the revival of instructional leadership has recommended clear definition of schools' instructional vision, effective classroom supervision, organizing school-based teacher professional development programmes among other things as foremost measures to be taken to improve this vital function of the school headteachers in question.
\end{abstract}

\section{Introduction}

One rarely disputes the fact about the efficacy of any educational programme, because its successful implementation hinges on how best it is managed at the school level. Thus, the role school-based leadership plays in successful implementation of educational programmes and policies is not only significant, but also very crucial. Fundamentally, a school headteacher is supposed to be seriously concerned with implementation of educational plans, programmes or policies. In this light, instructional leadership is the key to effective implementation of all sorts of educational programmes. And this by implication means that flaws, ineffectiveness, application of wrong leadership approaches, and lack of excellent instructional leadership qualities on the part of school headteacher could jeopardize successful accomplishment of educational programmes in no small measure. School heads whose primary concern should be to ensure that the school has been made conducive for teaching and learning, undertakes a cluster of duties and responsibilities via which the set school goals could be realized.

The fact remains that, the school headteacher is responsible for the general leadership in the school; he or she is equally in charge of staff personnel management, pupil personnel management, discipline, management of communication, supervision, instructional effectiveness, record keeping and reporting, financial and business management and so on. It could be asserted that out of all these manifold functions, curriculum and instructional leadership remain primarily important. This is because of the fact that right from the onset, schools are established to offer learning experiences in forms of skills, attitudes and other forms of expertise to the students, which in the end would manifest in the students' 
performance. School heads, according to Horng and Loeb (2010: 66), are held responsible for students' performance. It is in the light of the above significant position that instructional leadership occupies an important place in determining academic achievements of the students and the general school effectiveness. Thus, this paper has dwelt on the possible ways of revitalizing instructional leadership for successful implementation of UBE programme in Nigeria.

\section{The Concept of Instructional Leadership}

The concept of instructional leadership, being dynamic in nature, has recently metamorphosed into a cohesive and value-loaded activity which encompasses other vital leadership functions. Willison (2008: 2) observes in this connection that most definitions of the term (instructional leadership) have two elements in common; creating a school culture that makes student learning the top priority and providing the resources necessary to support teachers' efforts to improve student learning. Instructional leadership, according to Jenkins (2009: 35), reflects those actions a principal takes to promote growth in student learning. Thus an instructional leader is expected to make instructional quality the top priority of the school and makes attempts to bring that vision to reality. The National Association of Elementary School Principals (2001) in Jenkins (2009: 37) posits that, instructional leadership is a process of leading learning communities in which staff members meet on regular basis to discuss, reflect on their jobs, and take responsibility for what students learn. Horng and Loeb ((2010: 66) also comment in this respect that a different view of instructional leadership emphasizes organizational management for instructional improvement rather than day-to-day teaching and learning. Viewed from these perspectives therefore, instructional leadership involves developing a common vision of good instruction, building relationships, and empowering staff to innovate in instruction, give one another feedback and share best practices (Jones 2010: 38).

\section{UBE: the need to improve instructional leadership}

The UBE was launched in Nigeria in the year 1999 when the country assumed democratic rule after 16 years of military administration. Right from inception of the scheme, the Federal Government expressed resolve to pursue vigorously and with all its might the implementation of the programme poiting out that "the government is doing everything possible to ensure that the objectives of the programme are achieved" (Borishade 2001: vi) Basic education is without any doubt, very crucial owing to the fact this it is the foundation of the other levels of education as rightly pointed out by Tahir (2001: 2) that while education generally gives impetus to national development, basic education is its cutting edge. This he further observes is why the world over, there has always been the concern to provide basic education to the great majority of the people. Basic education, the writer concludes, not only lays the foundation for further education, it also equips beneficiaries with survival skills.

Although Basic Education originated from international commitment to education for all, the Scheme is seen as home grown, yet deeply rooted in global educational endeavours. It is in fact part of Nigeria's efforts to uphold and renew its commitment to the provision and promotion of basic education for all, as required by a number of covenants and protocols to 
which Nigeria is a signatory (UBE Digest 2001: 5) The Jomtien 1990 Declaration and Framework for action on basic education for all, the New Delhi 1991 Declaration, the Durban 1998 Statement of Commitment to the Promotion of Education for all, are cited among other protocols as the global basis of the programme. The programme is aimed at accomplishing the following objectives, as enshrined in the implementation guidelines:

- $\quad$ The provision of free, universal basic education for every Nigerian child of schoolgoing age

- $\quad$ Reducing drastically the incidence of drop-out from the formal school system (through improved relevance, quality and efficiency)

- $\quad$ Catering for the learning needs of young persons who for one reason or another, have had to interrupt their schooling through appropriate forms of complementary approaches to the provision and promotion of basic education

- $\quad$ Ensuring the acquisition of the appropriate levels of literacy, numeracy, manipulative, communicative and life skills as well as the ethical, moral and civic values needed for laying a solid foundation for life-long learning.(FME 2000 P7)

\section{Challenges of Instructional Leadership}

The UBE programme is not the first basic education scheme Nigeria had, rather in the year 1976 a similar programme tagged Universal Primary Education was introduced, but dropped due to financial, political and other problems. The UPE programme differed from the current UBE in a number of ways. For example, the scope of UBE is wider than that of the UPE. The UBE, unlike UPE, covers not only primary education but it also encompasses junior secondary schooling. This necessitates re-structuring and realigning the Nigerian Primary and Junior secondary school curriculum to meet the target of the 9-year Basic Education (NERDC $2007 \mathrm{P}$ iii). The revised curriculum which has been tailored towards meeting the Millennium Development Goals (MDGs) saw enrichment of it contents, reflecting emerging issues which covered value orientation, peace and dialogues, including human rights education, family, HIV and AIDS education, entrepreneurial skills and so on. All of these have been infused into the relevant contents of the revised 9-year Basic Education Curriculum. The Nigerian Educational Research and Development Council (NERDC), the organ of the Nigerian Ministry of Education charged with the responsibility of reviewing the curriculum has duly recognized the implication of this review for teachers and, indeed, their leaders pointing out that the inclusion of these new contents "have implications for what should be taught in schools, the way and manner in which they are to be taught, school organization and the classroom work".

Now taking the above developments into account, the school headteachers are tasked with the responsibility of reorienting their teachers to make them ready for the possible challenges they may face while teaching these newly infused contents. New methods, modernized approaches and well developed resources may be needed to effectively teach the new contents. The instructional leadership of the school would be expected to offer to teachers their teaching needs in congruence with the nature and objectives of the subjects, and the learning environment (classroom, laboratories etc). The teachers, in this case, need to be guided on how to enrich the contents of the curriculum with relevant materials and 
information from their immediate environments, but adapting the curriculum to their needs and aspiration (NERDC 2007: iv). The headteacher is expected in this regard to provide teachers with leadership role that will equip them with the necessary skills needed to enrich the curriculum contents and in the provision of required instructional materials in the absence of which improvisation would be a resort.

However, it is vital to point out that the needs for the school head teachers to revitalize their instructional leadership, is not only motivated by the above mentioned changes in the curriculum content, but there are other factors, such as poor conditions of learning, overcrowded classrooms, few or lacking in learning materials (etc) may be the additional vital factors that would necessitate improvement in the instructional leadership of the head teachers in Nigerian primary and junior secondary schools as observed by Ajayi (2001: 24). Thus the school head teachers in this respect are expected to revolutionize their curriculum and instructional management to the globally acclaimed instructional leadership. The school head teacher is in this regard confronted by the challenges of identification of instructional goals, effective instructional supervision, periodic review of progress so far made in the instructional development in the school, professional development of the teachers and acquainting teachers with the skills needed in improvisation of instructional materials.

\section{Improving Instructional Leadership}

As could be deduced from the discussions so far made, instructional leadership is deemed fundamental to successful implementation of not only the Nigerian Basic Education but also any other educational programme the world over. Simply because of the fact that the schoolbased instructional leadership is always responsible for guiding teachers on how to effectively undertake their instructional responsibilities applying appropriate techniques and employing right types of resources and methods have became necessary. This is especially true in this changing world in which new methods of teaching, sophisticated instructional materials and modernized pedagogical approaches are ushered in to classrooms on almost daily basis. (Bello 2012 p 30) Apparently, the dynamism of the world, improvements in curriculum contents, novelties in instructional techniques and advancement in Information and Communication Technology (ICT) and the general international trend in which emphasis is given to student performance and achievement, all call for a new approach to classroom instruction and in turn pose challenges to head teachers who are responsible for making sure that teachers are not only kept abreast with all the new developments taking place in the world of teaching, but also trending with such global practices.

As a leader, the school head teacher like any other organizational leader is provided with human and material resources to manage for the attainment of the goals and objectives for which the school is established. As a system, the school organization receives input, processes it consumes/uses and releases output. The input in relation to school organization includes the students, teachers, supporting staff, infrastructural and instructional facilities, financial resources, and so on. The students are the subject of the processing in the school organization in which they are transformed from unskilled to skilled, from not-knowing to knowing and from crude to discipline and eventually released as educated manpower which could be consumed by all other sectors of the society. 
Consequent upon the above proposition, it could be observed that the quality of education the students receive in school is determined by the quality of teaching, and this in turn depends not only on the teachers' preparedness but also on the quality of instructional leadership and guidance such teachers receive from the head teacher. For this and many other reasons the school head teachers should make instructional leadership their primary concern as implied by Horng and Loeb (2010: 66) that school leaders matter for school success. Halverson, Grigg, Prichett and Thomas (2005) state that, in this relation, while teachers are ultimately responsible for student learning in school, changing the organizational conditions for improvement is the central task of school leaders. The U.S department of Education (2005: 4) recognizes that instructional improvement is at the top of priorities of school principal.

To cope with the challenges posed by the need to effectively reshape their instructional leadership style for successful implementation of UBE in Nigeria, school head teachers must not be die-hard to the traditional approach to instructional leadership which is constrained to guiding the teachers on how to conduct teaching, but rather the full participation of both in all teaching and learning activities is strongly required in the modern instructional leadership approach. The head teacher should in this respect involve the teachers in defining the school's instructional goals, work together with them to strategize procedures for implementation, supervise the actual classroom teaching and advise teachers on improving their performance taking into cognizance the students' achievement. Here a good number of models applicable to all school organizations have been developed by scholars and researchers and these include Perspective Models, Transformational Model, Path-Goal Model, Situational Theories, Exploratory Studies of Direct Effects of Principal-teacher Instructional Conference, Studies of Direct Effects of Principal Behavior on Teachers and Classroom Instruction and many others (Blasé and Blase 2000: 130-131). However, one of the widely recognized models which is also adapted in this presentation is that of Hallinger and Associates which Hopkins (2003: 3) describes as the most fully tested approach to instructional leadership. The model consists of ten specific functions condensed within three broad categories:

- $\quad$ Defining the school's mission

- $\quad$ Managing the instructional program and

- $\quad$ Promoting a positive learning school climate

Hallinger (2009 p 6) postulates that for the purpose of defining the schools' goals, two functions have to be conducted, and these are framing clear school goal and communicating clear school goals. For managing instructional program, the writer proposes supervising and evaluating instruction, coordinating curriculum and monitoring students' progress. The function of promoting a positive learning climate entails protecting instructional time, promoting instructional development, maintaining high visibility, providing incentives for teachers and providing incentives for learning.

The possible starting point for effective and result-oriented instructional leadership in the Nigerian Basic Education Schools should be a change of approach from the part of the school head teachers to make students' learning their priority and then make a resolve to improve all the teaching and learning activities in the school. The head teachers should then meet with 
the teachers to define the instructional goals of the school and decide on how to pursue vigorously these goals. The teachers' involvement in this task of goal setting should feature series of meetings to identify the common instructional problems in the school. Such identified problems should then be changed to needs. For instance, if problems such as dearth of instructional materials, poor reading culture of the students, application of ineffective teaching methods, lack of interest in a particular subject, mass failure in examinations and the like have been identified as the instructional weakness in the school, then these problems could be changed to needs as follows:

- To ensure adequate supply of instructional materials and or train teachers on how to improvise the materials

- To develop positive reading culture among the students

- $\quad$ To acquaint teachers with modern teaching methods etc.

In addition to the above, the school Principals must demonstrate through their actions that teaching and learning are the centre of what happens at school, and the principal should constantly be visible in the classroom in order to learn more about instructional practices within the school and to provide feedback teachers can use to inform and improve their own practices (Willison 2008 p 4)

\section{Recommendations}

Generally speaking, the major instructional leadership challenges facing school head teachers in the Nigerian Basic Education Schools, which call for revitalization of instructional leadership for effective implementation of UBE as discussed in this write-up, revolve around goal identification, provision of adequate instructional materials, teacher development, collaborating with teachers to get better the general conditions of learning as well as effective instructional supervision. It is based on these identified challenges that the following recommendations are offered:

- Revolutionize instructional leadership style to conform with the new trend in which students' achievements and performances are given priority. This entails cooperating with teachers to determine the instructional goals of the school, and map out strategies via which such goals could be accomplished. The task of defining schools' instructional goals could be more productive, if the head teacher incorporates others. This would allow for generating and sourcing as many contributions as possible. The head teacher could then sit down and refine the ideas and finally come out with clearly defined instructional vision statement which the school will try to pursue within a specified time frame. This must be communicated to all stakeholders in the school.

- Apart from encouraging teachers to be part of the planning for the general improvement of instructional activities, the head teachers should also supervise the teaching activities in the classrooms and see how the teachers teach and how the students learn. By doing so, the head teachers could obtain first-hand information upon which further actions could be taken to reinforce good practices and rectify shortcomings. It is perhaps in this relation that Willison (2008: 2) suggests that the 
head teacher should utilize time spent in the classroom to identify outstanding teachers and their methods, and in turn provide opportunities for those superstar teachers to share what they are doing with their colleagues.

- Confer with teachers periodically to review the situations in order to see the progress so far recorded, grey areas that need to be corrected and decide on how to improve the situation. The school leaders can provide teachers with regular feedback on student progress and since changes that last depend on the effectiveness of their efforts, teachers need tangible evidence that students are growing (U.S Department of Education 2005: 7).

- $\quad$ Conduct periodically professional developmental programmes for teachers to improve their performance. Teachers want their students to succeed, and given the proper training and support, they are willing to do what is necessary to improve school achievement (U.S Department of Education 2005: 7).

- Develop in teachers the culture of collaborative approach to teaching. The principals, observes Finkel (2012: 4), need to guide teachers away from thinking of themselves as masters of their classroom, and toward a more collaborative style to work together on the common goals laid through accountability measures. He concluded that it is impossible for every teacher to provide everything-to have all content knowledge and pedagogical knowledge.

- Guide teachers on how to improvise instructional materials so that dearth of instructional materials would not deter teachers from making impact on students' learning.

\section{Conclusion}

Albeit, the fact that the Nigerian Basic Education Programme is home grown, its origin is traceable to international trends manifesting in the attempt at providing education for all which is one of the Millennium Development Goals. The inception of the programme saw a number of changes in the school curriculum to conform to the global trends and this in turn necessitates that the head teachers managing Nigerian Basic Education Schools have to change their instructional leadership style. Thus revitalizing instructional management approaches the head teachers apply become inevitable. Internationally, a number of new approaches and models of instructional leadership have been developed by seasoned scholars, practicing educational administrators and researchers which have potentialities of making school organization a conducive place for effective teaching and learning. Some of such theories and models have been synoptically reviewed in this paper with special emphasis on Hallinger's model of Instructional Leadership. It is based on the postulations of those models that recommendations were offered on how the head teachers could improve their instructional leadership approach for successful implementation of Universal Basic Education in Nigeria. 


\section{References}

Ajayi, T. (2001). Effective Planning Strategies for UBE Programme, in UBE Forum, 1 (1): 24.

Bello, A. B. (2012) Management of Primary Education in Nigeria: Synopses on some problems and panaceas, in Bayero Journal of Education in Africa, 1 (1): 30.

Blasé, J and Blasé J (2000). Effective Instructional Leadership; Teachers' Perspectives on how Principals Promote Teaching and Learning in Schools, in the Journal of Educational Administration, 38 (2) http://www.emerald-library.com. Retrieved on $18^{\text {th }}$ October 2013.

Borishade, B (2001). Foreword to the Maiden Edition, UBE Forum, 1 (1): Vii.

Federal Ministry of Education, (2000). Implementation Guidelines for the Universal Basic Education (UBE) Programme, Abuja, NERDC Press.

Finkel, E. (2012). Principals as Leaders; in District Administration; Solution for School District Management.www.amozon.com/principals-instructional-leaders-District retrieved on 18th October 2013.

Hallinger, P. (2009) Leadership for $21^{\text {st }}$ Century Schools: from Instructional Leader to Leadership for Learning, Hong Kong, the Institute of Education, China. www.ied.edu.hk/c/cplectures/include/getfile.php retrieved on 18th October 2013

Halverson, R, GriggJ, Prichett R \& Thomas, C (2005). The Instructional Leadership: Creating Data-Driven Instructional System in Schools www.academiccolab.org/resources/documents/HajersonGrigg retrieved on $4^{\text {th }}$ July 2013.

Hopkins, D. (2003). Instructional Leadership and School Improvement: the National College for School Leadership.www.teachingtimes.microsoft.com.paper/5027376aspxRetrieved on 18th October 2013.

Horng, E. \& Loeb S. (2010). New thinking about Instructional Leadership, in Kappa Magazine, 92 (3): 66.

Jenkins, B. (2009). What it takes to be an Instructional Leader? www.naesp.org

Jones, D. R. (2010). Instructional Leadership Quandrant D Leadership Practices Resource Kit, USA International Center for Leadership in Education.www.leadershipEd.com retrieved on $10^{\text {th }}$ August 2013.

Nigerian Educational Research and Development Council (2007). 9-.Year Basic Education Curriculum, English Studies for Primary 3, Abuja, NERDC Press.

UBE Digest (2001). A Newsletter of Basic Education in Nigeria, 1 (1): 5. 
U.S Department of Education (2005). What is instructional leadership and why is it so important? Reading First Notebook http://www.readingfirstsupport.us. Retrieved on $10^{\text {th }}$ August 2013.

Tahir, G (2001) Federal Government Intervention in Universal Basic Education, in $U B E$ Forum, 1 (1): 2.

Willison, R. (2008). What makes an instructional Leader, in The Scholastic Administrator? www.scholastic.com/browse/article.jsp=3748622 retrieved on $18^{\text {th }}$ October 2013 . 